\title{
The Characteristic of the Phenomenon of Adaptation as an Active Psychological Process
}

\section{Характеристика феномену адаптації як активного психологічного процесу}

Elina Hlavinska

Postgraduate Student, Rivne State University of the Humanities, Rivne (Ukraine)

ORCID ID: https://orcid.org/0000-0002-7670-4931

Researcher ID: http://www.researcherid.com/rid/ABB-1976-2021

E-mail: elin.belka@gmail.com

\section{Еліна Главінська}

Аспірант, Рівненський державний гуманітарний університет, м. Рівне (Україна)

\section{ABSTRACT}

The purpose of this article is: to show the process of adaptation as an active psychological process, which is influenced by both external (objective) and internal (subjective) factors; to express the main ideas of the Rational-Humanistic Approach, the Psychoanalytic direction, a Conative and a Cognitive models, a Socio-psychological direction.

The following theoretical methods of the research were used to solve the tasks formulated in the article: a categorical method, structural and functional methods, the methods of the analysis, systematization, modeling, generalization.

The results of the research. Thus, destructive behavior is performed with a very specific purpose. Such behavior always requires special attention. It can

Address for correspondence, e-mail: kpnu_lab_ps@ukr.net Copyright: (C) Hlavinska Elina

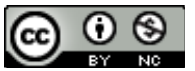

The article is licensed under CC BY-NC 4.0 International

(https://creativecommons.org/licenses/by-nc/4.0/)

(c) Hlavinska Elina

DOI (article): https://doi.org/10.32626/2227-6246.2021-54.09-33 
cause anxiety, irritation, especially if children see this as the only one way for their parents to notice them, take care of them, to deal with them. Demonstrative disobedience of children, as a rule, is a consequence of a completely wrong conclusion of children that they can assert themselves, insist on the fulfillment of their desires, proving their strength in a case of confrontation with adults. Revenge, retribution, and the desire to hurt others sometimes seem to children to be the only way to feel themselves important and meaningful.

Claiming their inability or inferiority, demonstrating real or imagined powerlessness, as a rule, we have to refuse to communicate with parents, do not want to carry out assignments, to be irresponsible to the whole process of our life.

Conclusions. The purpose of psychological assistance to parents according to socio-psychological direction should be to help both adults and children to master as many appropriate types of social interaction. Such kind of interaction should be built on the basis of completely identical or fairly close ideas about values and mutual respect of people of each other. One of the main tasks of family upbringing is to help a child become a competent person who will be able to use constructive psychological mechanisms and means independently to form a sense of self-worth and to master a certain, the most important for the child social status.

The remarkable relevance of the ideas of A. Adler (1998) and $R$. Dreikurs (1986), no doubt, is associated with the crisis, in which the family found itself in the first half of the last century. Traditional relationships between parents and children, organized according to the principle of superiority and subordination, have proved to be extremely ineffective. According to the authors, parents who continue to communicate with their children from the standpoint of power and superiority, do not realize that children perceive them as equal partners in the whole process of communication. Top-down conversation with children usually leads to children's mind, in turn, in the same way they begin to communicate with their parents or even shut themselves in, try not to react to parents and, at the end, even despise them.

Thus, R. Dreikurs (1986) was one of the first persons who started discussions in the training groups of parents who were living in the neighborhood. He assumed that parents would share their experiences, ask questions and seek support, form approval from the side of the group. The main task of the group leader was to organize the discussion skillfully, to make formulation of questions, and each member of the group could periodically perform the role of group leader in the case of exchange of certain information and provide the expertise.

(C) Hlavinska Elina

DOI (article): https://doi.org/10.32626/2227-6246.2021-54.09-33 
DOI: https://doi.org/10.32626/2227-6246.2021-54

2021. ВИПУСК 54

Key words: the adaptation, destructive behavior, demonstrative disobedience, demonstrating real or imagined powerlessness, a case of confrontation with adults.

\section{Introduction}

The process of adaptation in psychological issues is understood as a human adaptation to environmental conditions, which in some adverse cases actualizes the mechanism of psychological protection (Brédart, 1991). There are many reasons, such as the state of mental tension, stresses, emotional burnout which weaken the mechanisms of psychological protection of the individual, leading to his/her maladaptation in the society.

We've to admit, that there is no generally accepted definition of the concept of "adaptation" in modern scientific literature, but common to all theoretical and methodological approaches is that the process of adaptation involves the interaction of at least two subjects; such interaction unfolds in special conditions of imbalance, inconsistency between different systems; the main purpose of such interaction is some coordination between systems, the degree and the nature of which can vary widely; achieving the overall goal of the subjects of social interaction involves, in turn, significant changes in the systems that interact.

Adaptation involves, as a prerequisite, the interaction of the individual with the world around him allows the subject to realize their current and potential opportunities, as well as the need and willingness to implement them (Crookes, 1989). As a result, a person is seen not only as the object of some adaptive influences, but the individual is quite differently aware of the changes taking place around him/her, as well as experiencing these changes in the structure of his/her «Me», actively and independently forms the necessary strategies for adaptation not only for the dynamic external world, but also to the acquired new roles and positions.

(c) Hlavinska Elina

DOI (article): https://doi.org/10.32626/2227-6246.2021-54.09-33 
DOI: https://doi.org/10.32626/2227-6246.2021-54

2021. випУСК 54

So, the purpose of this article is: to show the process of adaptation as an active psychological process, which is influenced by both external (objective) and internal (subjective) factors; to express the main ideas of the Rational-Humanistic Approach, the Psychoanalytic direction, a Conative and a Cognitive models, a Socio-psychological direction.

\section{Methods of the research}

The following theoretical methods of the research were used to solve the tasks formulated in the article: a categorical method, structural and functional methods, the methods of the analysis, systematization, modeling, generalization.

\section{Results and their discussion}

Thus, adaptation is an active psychological process, which is influenced by both external (objective) and internal (subjective) factors, the harmonious influence of which ensures the effective interaction of the individual with others. If there is an imbalance of these conditions, then, as a result, there is maladaptation, which is reduced the adaptive mechanisms, violation of the harmonious integration of the individual with the environment (Максименко, Ткач, Литвинчук \& Онуфрієва, 2019). In the scientific literature, maladaptation is often seen as a violation of the adaptation process, as the indicator of imbalance of personal traits, as a consequence of the inability of the individual to meet his/her needs without conflict with himself/herself and his/her surroundings.

The process of adaptation can be defined by the term «adaptation». It is the state of the organism as a result of successful implementation of the process of adaptability. Maintaining the differences in the state of the organism before and after the process of adaptation is adaptive effect. If intraindividual mental characteristics, personal traits are formed under the influence of various psychological factors, the complex of men(C) Hlavinska Elina

DOI (article): https://doi.org/10.32626/2227-6246.2021-54.09-33 
DOI: https://doi.org/10.32626/2227-6246.2021-54

2021. випуск 54

tal qualities having been formed in response to their influence can be manifested in either adaptive or maladaptive forms of the behavior of the individual (Mykhalchuk, \& Ivashkevych, 2019).

In Psychology there are some dominant approaches, explaining the causes of maladaptive behavior of the person. They support the main reasons of adaptation into the paradigm of parent-child relationships. Scientists distinguished Psychoanalytic, Cognitive, Conative, Ratio-Humanistic and Socio-psychological approaches. These approaches show different explanations of maladaptive behavior of the person. It has been determined that, according to the Psychoanalytical approach, the state of frustration was arising from the conflict of the person and social environment. They all are the causes of maladaptive relationships. In the Conative paradigm, maladaptive behavior is seen as the result of the individual's mastery of providing destructive reactions. In such a way, the Cognitive approach explains the maladaptive behavior of emotional disorders related to the erroneous of cognitive interpretation of the person by a particular event. Another, Ratio-Humanistic approach emphasizes that the reason for maladaptive relationships is the mismatch between a "real Me» of the person and his/her life experience, on the one side, and a «real Me» of the person and an «ideal image of Myself» having been formed by a person for himself/herself, on the other side. Within Socio-psychological approach maladaptive behavior is explained by the individual's unwillingness to perform certain social ways of personal growth. It helps person to make decisions about value orientations and one's own way of life (Комплієнко, 2020).

Many researchers (Mykhalchuk \& Onufriieva, 2020) explain the causes of maladaptive behavior, the identifying of disorders associated with adaptation, indifference, humility, independence from social norms, rules, self-depreciation, addictions, alcoholism as well as the reaction to discrimination on various grounds.

(C) Hlavinska Elina

DOI (article): https://doi.org/10.32626/2227-6246.2021-54.09-33 
DOI: https://doi.org/10.32626/2227-6246.2021-54

2021. випуск 54

In modern researches (Vovk, Emishyants, Zelenko, Drobot \& Onufriieva, 2020) there were named some personal characteristics, such as aggression, anxiety, selfishness, dependence, despotism, stubbornness, secrecy, etc., which could cause maladaptive behavior. As a result, the individual has great difficulties in adapting in relationships with others, which greatly affects the nature of his/her interaction and generates completely maladaptive reactions. Scientists (Mykhalchuk \& Kryshevych, 2019) believe that the functions of maladaptation are manifested primarily in the sphere of conflicts, overcoming which it facilitates the emergence of quite constructive changes in interpersonal relationships.

In this case we mean changes that contribute to the formation of adaptability in the child-parent relationships. Personality adaptability in family relationships is a dynamic process of parent-child interaction in a new system of family relationships (complicated by the child's use of psychoactive substances), mastering new roles and a new way of My own Image (the formation of self-identity).

In such a way we'll try to explain the adaptive parent-child relationships in the family. We've to note that we consider such relationships as a process of psychological response to the behavior of people, when the form of the content and the intensity of reactions are also adequate for solving the main problem in the relationships. That's why the adaptive parentchild relationships in the family significantly facilitate the resolution of conflict situations or the situations of cognitive dissonance.

The researchers emphasize the importance of the person's attitude to the phenomena around him/her and other personalities. In such a way researchers define the concept of «Psychological attitude» as a fairly holistic system of the individual, which shows conscious connections of the Person with various aspects of objective reality. That's why Psychological attitude is a system that influences the process of human development. (C) Hlavinska Elina

DOI (article): https://doi.org/10.32626/2227-6246.2021-54.09-33 
DOI: https://doi.org/10.32626/2227-6246.2021-54

2021. виПУСК 54

It actualizes his/her personally significant experience, determines the actions and the experiences of the individual. For example, in the paradigm of Ratio-Humanistic Approach G.O. Ball (1996) understands the attitude as a kind of psychological phenomenon, the essence of which is the emergence of the person's mental perception of the reality, which accumulates the results of knowledge of a particular object of the environment, the integration of emotional responses to this object, as well as his/her behavioral acts on the latter.

Another representative of the Rational-Humanistic Approach is S.V. Kovalev (1987). In the structure of adaptive relationships S.V. Kovalev identifies three components: a cognitive one, the emotional component and a behavioral one. Normally, a person on a cognitive level knows something about the object, on the emotional level he/she experiences the emotions corresponding to this knowledge, on a behavioral level the person builds his/her own behavior, a reaction that corresponds to a certain knowledge and emotions. In pathology, the components of the relationships are usually inconsistent, which in most cases lead to neurotic disorders and maladaptation. The destruction of the holistic system of relationships, which leads to neuroses, is usually the result of a violation of the integrity of the system of relationships (their hierarchical structure). The presence of contradictory relationships, which is equally important for the individual, leads to inadequate interpersonal relationships and, as a consequence, to maladaptation.

Based on the analysis of the theory of relations (Blagovechtchenski, Gnedykh, Kurmakaeva, Mkrtychian, Kostromina \& Shtyrov, 2019) the concept of «interpersonal attitude» is considered as subjectively experienced relationships. In such a way different connections between people are objectively manifested in the nature and by the ways of mutual influence of people on each other in the process of joint activities and communication.

(c) Hlavinska Elina

DOI (article): https://doi.org/10.32626/2227-6246.2021-54.09-33 
DOI: https://doi.org/10.32626/2227-6246.2021-54

2021. випуск 54

We attribute interpersonal family relationships to individual cases of psychological relationships and consider them as the most important of the conditions of mental development, socialization, the formation of specific individual traits, characteristics, personal development in general. Interpersonal relationships appear as some internal psychological category and they are understood as a mutual emotional, figurative, cognitive reflection of one person in the inner world of another one.

The concept of «child-parent relationship» is defined as a process and as a result of individual reflection of family connections that mediate the internal and external activity of parents and children in their joint lives. In the communication of parents and children from the very birth of the latter it is the formation of the psyche of children and, at the same time, due to this significantly changes according to the mental life of parents. We analyze the parental attitude to the child as a special, cultural and historical phenomenon as a rather variable phenomenon, which is significantly influenced by social norms and values.

The child-parent relationships in their forms develop a holistic system of psychophysiological, sensory and social connections between parents and children, due to family experience of the process of communication. The nature of this relationships is revealed on the basis of empirically researched and tested reactions of parents and children to each other.

According to the child-parent relationships, the concept of «harmonious child-parent relationships» is the most appropriate. Harmonious relations take their place when there are no antagonistic contradictions between the subjects of interpersonal interaction. All the contradictions that exist must be resolved constructively, and then we can talk about the development of the family. Such it is, for example, the relationships between parents and children, if both parties fully accept each other as they are. In the process of life, harmonious childparent relationships are quite rare, but it makes sense to talk (C) Hlavinska Elina

DOI (article): https://doi.org/10.32626/2227-6246.2021-54.09-33 
about them as some of the ideal presents to which relatives should strive.

We'd like to consider several theoretical approaches to understand the role and the content of child-parent relationships, formulated by various of the most well-known psychological schools.

One of the most important advantage of the psychoanalytic direction is that its founders paid a lot of attention to the greatest early experience of interaction between parents and children and to various types of mental trauma in childhood. (Фрейд, 1989; А. Фрейд \& 3. Фрейд, 2000; Хорни, 1988; Фромм, 1992). Central place in the study of child's development in the paradigm of psychoanalytic direction is traditionally given to sexuality, aggression, as well as feelings such as hunger, suffering. According to Z. Freud and A. Freud (2000), the mother appears for the child, on the one hand, as the basic and the most important source of pleasure, as an essential object of libido, and, on the other hand - as so-called «legislator» and "controller». It should also be emphasized that the usual daily actions of parents have to be directed to care for a child, to have a remarkable psychological effect. The way and the completeness of meeting reveals the biological needs of the child in the early stages of life lay a great foundation of trust, commitment, activity towards other people for the rest of life.

Flexibility, patience, reasonable demands of parents, support of the child's efforts greatly contribute to the formation of adequate forms of self-regulation, positive self-esteem, as well as creative thinking. In addition to purely biological factors, the representatives of this trend emphasize the role of the relationships between a child and a mother at the early age, which affects the formation of the person. Psychoanalytic parenting theory focuses on the relationships between the child and the mother and the role of the mother, who cares, gently feeds, who meets the needs of the child and with whom the child feels himself/herself completely safe. The bond between 
DOI: https://doi.org/10.32626/2227-6246.2021-54

2021. випУск 54

the child and the mother continues to develop the child's social and empathic feelings and desires, and then this is reflected in the personality of the adult, affects the formation of his/ her person.

Psychoanalysts have paid close attention to the therapy of a family and parents, so this approach is often used in complex cases that require outside intervention. E. Fromm's (1992) point of view was also widely recognized, who, considering the child-parent relationships as a fundamental basis for the child's development, emphasized the qualitative difference between the peculiarities of maternal and paternal attitude to the child. Maternal love, says the scientist, is an "unconditional characteristic», it cannot be controlled by the child, it cannot be deserved, it either exists or it does not exist. Parental love, in contrast, is due to the fact that the father likes the fact that the child meets his expectations.

D. Winnicott's (1994) issues emphasize the influence of the social environment on the psycho-emotional development of the child and the importance of maternal care for the formation of the personality psyche. The author emphasizes the need to change the relationships with the child in a view of growing up. The scientist also points out that fatherhood has to go through several stages from the complete loss of personal independence of the mother at the birth of a child to the restoration of this independence in the fight against the demands of the child. Thus, along with the personality of the father, a full-fledged independent personality of the child is formed.

The American psychologist E. Erickson (1996), based on his research on the psychoanalytic preconditions for the formation of the person, concluded that the rational adaptation of a man to the social environment, the need for each individual to resolve, not psychosexual, but psychosocial conflicts, thus overcoming life's difficulties and problems. The basics of forming a healthy personality is a basic sense of trust in the world (inner certainty), autonomy (independence, feelings, (C) Hlavinska Elina

DOI (article): https://doi.org/10.32626/2227-6246.2021-54.09-33 
which are formed by self-control), initiative actions (the ability to formulate tasks to experience their own activity, such as psychomotor and social ones) - all these factors are actualized by the adequate, balanced parental position, by confidence, reliability, encouragement of independent action), and they are increase in the psychological space controlled by each child.

Thus, K. Horney (1988) argued that the social relationships between a child and parents are the decisive factor in the development of the person. According to K. Horney (1988), in the childhood the basic needs are to meet security. If the behavior of the parents does not help to meet the child's need for security, it leads to basal hostility, and it, in turn, leads to the emergence of basal anxiety. K. Horney (1988) studied the transfer of intrapersonal conflicts to the mother's attitude to the child. The scientist identified psychological factors that can harm the desired maternal position, and also he identified the sources from which these factors were originated.

In order to create a Conative model of bringing children up, scientists have conducted some empirical studies. With their help, an attempt was made to determine how the attitudes and the behavior of parents affect the child. This model emphasizes that the behavior of parents and children can be completely changed by relearning both the first and the second stages.

Scientists focused on the problem of teaching children. Particular attention was paid to such forms of environmental changes that lead to the child's re-learning, to the child's mastery of new personal experiences. The purpose of raising children is to teach them to be "moderators of their behavior». In such a way they are not able to build a model of the environment independently.

According to the basic idea of the Conative direction, the behavior of parents changes as a result of their understanding of their own behavior and the behavior of children. Gradually, parents acquire the ability to manage the relatives around (C) Hlavinska Elina

DOI (article): https://doi.org/10.32626/2227-6246.2021-54.09-33 
DOI: https://doi.org/10.32626/2227-6246.2021-54

2021. випуск 54

them, which is influenced the behavior of all family members, and to regulate family relationships. The basic paradigm of psychologists of the Conative direction is the statement that parents can always teach children appropriate behavior, and these parents should only understand the principles of social learning and apply them to their children.

Representatives of this direction usually distinguish three ways of the formation of adequate behavior of children: positive reinforcement (encouragement); negative reinforcement (punishment); lack of reinforcement (zero attention). In the paradigm of Cognitive learning models parents are taught to apply these psychological strategies in different situations that are arisen between parents and children. Thus, the model of upbringing is based on the fact that is changed in the family environment. It is led to different changes in the behavior of both parents and children. Therefore, parents can play the role of «managers» who will regulate the behavior of their children through significant changes in living conditions. At the same time, parents themselves are taught to understand children's reactions, to change children's behavior with the help of behavioral analysis techniques. That is, children's education is based on the principles of systematic confirmation of the implementation of activities under certain laws. For example, some scientists (Гончарук \& Онуфрієва, 2018) note that Conative theory ignores the traditional ideal of human value and individual freedom - the definition of patterns of the person's behavior of both parents and children, as a rule, is transferred from the individual to his/her environment. At the same time, both people at the individual and social levels demonstrate such patterns of the behavior and such psychological preconditions which are created that guarantee the appropriate behavior of each individual for the certain society, prevent the decomposition of social relations and the destruction of the humanity as a whole. From a practical point of view, such a model of raising children creates positive conditions for parents to manage (C) Hlavinska Elina

DOI (article): https://doi.org/10.32626/2227-6246.2021-54.09-33 
their own behavior and the behavior of their children and, if it is necessary, to create the desired conditions for changing patterns of the person's behavior.

C. Bütner (1991), a representative of Socio-psychological direction in the research of the person, emphasized that parental behavior is a model for identifying some common traits and rules of behavior. It is like a model for the child to follow in trying to build his/her own strategic concept of the behavior. The psychological mechanism of reinforcement is essential for the preservation of different patterns of the behavior, and it arises on the basis of the mechanism of imitation. In such a way C. Bütner also notes that rewards and punishments are not enough to teach a child new patterns of the personal behavior. Children learn new patterns of the behavior primarily due to the imitative psychological mechanisms. Learning through observation, imitation and identification is another form of teaching. After all, imitation-identification is a process in which a person seems «to borrow» certain thoughts, feelings or actions of another person, who performs a kind of a role model for the first person. The process of imitation helps the child to imagine himself/herself in the place of a certain model, to feel compassion, complicity, empathy before this person. Thus, socio-cognitive direction of the old stereotypes of the behavior of parents and children are questioned in terms of compliance with a social reality, and they are consistently replaced by new, corresponding stereotypes to the reality around us.

One of the most well-known approaches to understand adequate family upbringing was developed by A. Adler (1998), the author of the individual theory of the Personality. According to A. Adler (1998), the man is a social being, and the development of the Personality should be considered, above all, the next paradigm of social relations. The theory of the Personality, developed by A. Adler (1998), emphasizes that each person has an innate sense of joint activity (or life), or a common social interest (such as «natural desire to cooperate»), as well 
DOI: https://doi.org/10.32626/2227-6246.2021-54

2021. випуск 54

as the desire for perfection, which realizes the uniqueness of the individual and provides creative characteristics of a human «Me».

The main psychological determinants of family upbringing, according to A. Adler (1998), are such, as: equality, but not identity between parents and children, both in terms of rights and responsibilities, and in terms of personal responsibility; cooperation; harmonious results of family upbringing. Parental upbringing is based primarily on conscious and purposeful personal change of parents, which is determined by the guiding principles of mutual respect of family members to each other. The feeling of unity, that is arisen, makes a person able to cooperate with other people, to develop the forms the social character of each family member. It should be born in mind that since the development of the Personality it is determined by social motives, and the man is a social being by nature. It is important for him to feel a sense of belonging to a particular social group. According to A. Adler's theory (Адлер, 1998), the family atmosphere, attitudes, values and relationships in the family are the main psychological factors in the development of the Personality. Children learn to live together and perceive World culture through the example of their parents. Therefore, the family is the primary group in which the child forms his/her ideals, life goals, value system and, thus, learns to live. Given this model, the help of parents in relations to their children should be educational by its nature. It is necessary to teach children to respect the uniqueness, individuality and inviolability of the child's personality from the earliest childhood. It is also necessary to help each parent to understand their children, as if «to enter» the paradigm of their way of thinking, to learn to understand the motives for actions and deeds, and, at the same time, to create their own methods of education and personal development. Natural logical reasoning, which is used in the process of family upbringing, allows the child by practice to understand his/her behavior or to feel (c) Hlavinska Elina

DOI (article): https://doi.org/10.32626/2227-6246.2021-54.09-33 
DOI: https://doi.org/10.32626/2227-6246.2021-54

2021. випуск 54

in practice the results of the child's actions. This significant contribution to the harmonization of relationships in the family and the child's rapid awareness of the shortcomings depends on their own behavior.

A. Adler's dream (Адлер, 1998) was to create a real community of like-minded people, such as parents, teachers and others, adults, who are interested in raising their children, who would work together to promote the development of courage and social responsibility of the younger generation. And one of the first students who realized his teacher's dream was R. Dreikurs (1986). A remarkable advantage of the activity of a scientist was the active implementation of A. Adler's ideas (Адлер, 1998) in practice. Empirical research having been done by R. Dreikurs (1986) emphasized the importance of the process of socialization that took place in the family. According to R. Dreikurs (1986) a child's way of life can only be truly understood when his/her relationships with other family members in a specific family environment become in a great degree clear. The family environment does not force the child to behave in a certain, clearly defined manner. It simply shows how the child came to his/her beliefs, views, points of view. At the same time, the child participates quite early in the process of the formation of their relationships with other people. The family atmosphere, of course, largely depends on the values and family traditions within the family. It creates so-called initial, psychologically determined social environment in which the child's personality is formed. From the acquired personally significant experience the child masters the idea of himself/herself, of other people and the World as a whole. Thus, R. Dreikurs (1986) singled out four reasons for the child's negative behavior: the requirement for attention or comfort; the desire to show the power of children or to provide demonstrative disobedience; revenge, retribution; assertion of their insolvency or inferiority. Also R. Dreikurs (1986) claimed that he had never met a child between the ages

(C) Hlavinska Elina

DOI (article): https://doi.org/10.32626/2227-6246.2021-54.09-33 
DOI: https://doi.org/10.32626/2227-6246.2021-54

2021. випуск 54

of 9 and 12 whose undesirable behavior would not fit into one of these four patterns of negative causes.

R. Dreikurs (1986) pays special attention to the interpretation of destructive behavior of children directed on their parents. At the same time, forms of such behavior are considered by us as some purely erroneous approaches, using which children try to find their place within the family or other social group and provide a sense of belonging, security and recognition.

Thus, destructive behavior is performed with a very specific purpose. Such behavior always requires special attention. It can cause anxiety, irritation, especially if children see this as the only one way for their parents to notice them, take care of them, to deal with them. Demonstrative disobedience of children, as a rule, is a consequence of a completely wrong conclusion of children that they can assert themselves, insist on the fulfillment of their desires, proving their strength in a case of confrontation with adults. Revenge, retribution, and the desire to hurt others sometimes seem to children to be the only way to feel themselves important and meaningful.

Claiming their inability or inferiority, demonstrating real or imagined powerlessness, as a rule, we have to refuse to communicate with parents, do not want to carry out assignments, to be irresponsible to the whole process of our life.

\section{Conclusions}

The purpose of psychological assistance to parents according to socio-psychological direction should be to help both adults and children to master as many appropriate types of social interaction. Such kind of interaction should be built on the basis of completely identical or fairly close ideas about values and mutual respect of people of each other. One of the main tasks of family upbringing is to help a child become a competent person who will be able to use constructive psychological mechanisms and means to form a sense of self-worth (c) Hlavinska Elina

DOI (article): https://doi.org/10.32626/2227-6246.2021-54.09-33 
independently and to master certain, the most important social status for the child.

The remarkable relevance of the ideas of A. Adler (1998) and R. Dreikurs (1986), no doubt, is associated with the crisis, in which the family found itself in the first half of the last century. Traditional relationships between parents and children, organized according to the principle of superiority and subordination, have proved to be extremely ineffective. According to the authors, parents who continue to communicate with their children from the standpoint of power and superiority, do not realize that children perceive them as equal partners in the whole process of communication. Top-down conversation with children usually leads to children's mind, in turn, in the same way they begin to communicate with their parents or even shut themselves in, try not to react to parents and, at the end, even despise them.

R. Dreikurs (1986) was one of the first persons who started discussions in the training groups of parents who were living in the neighborhood. He assumed that parents would share their experiences, ask questions and seek support, form approval from the side of the group. The main task of the group leader was to organize the discussion skillfully, to make formulation of questions, and each member of the group could periodically perform the role of group leader in the case of exchange of certain information and provide the expertise.

\section{Literature}

Адлер А. Воспитание детей. Взаимодействие полов. Ростов-на-Дону : Феникс, 1998. 112 с.

Балл Г.О. Про психологічний зміст вільного розвитку особистості. Психологічні аспекти гуланізацї̈ освіти, 1996, 53-67. Київ - Рівне.

Бютнер К. Зћить с агрессивными детьми / пер. с нем. Москва : Педагогика, 1991. 41 с.

Винникотт Д.В. Разговор с родителями. Москва : Класс, 1994. 112 с.

Гончарук Н., Онуфрієва Л. Психологічний аналіз рівнів побудови комунікативних дій. Psycholinguistics. Психолінгвістика. Психолинг-

(C) Hlavinska Elina

DOI (article): https://doi.org/10.32626/2227-6246.2021-54.09-33 
DOI: https://doi.org/10.32626/2227-6246.2021-54 2021. випуск 54 вистика, 2018, 24 (1), 97-117. DOI https://doi.org/10.31470/23091797-2018-24-1-97-117.

Дрейкурс Р. Счастье вашего ребенка: книга для родителей. Москва : Прогресс, 1986. 236 с.

Ковалёв С.В. Психология семейных отношений. Москва : Педагогика, 1987. 159 c.

Комплієнко I.O Теоретичний аналіз проблеми дезадаптивних взаємостосунків батьків та дітей. Ажтуальні проблели психології. Методологія і теорія психологї: Зб. наук. праць Інституту психологї іл. Г.С. Костюка НАПН України, 2020, XIV (3), 99-113. Київ Ніжин.

Максименко С., Ткач Б., Литвинчук Л., Онуфрієва Л. Нейропсихолінгвістичне дослідження політичних гасел із зовнішньої реклами. Psycholinguistics. Психолінгвістика. Психолингвистика, 2019, 26 (1), 246-264. DOI 10.31470/2309-1797-2019-26-1-246-264. URL : https://psycholing-journal.com/index.php/journal/article/ view/715.

Фрейд А., Фрейд 3. Детская сексуальность и психоанализ детских психоневрозов. Санкт-Петербург : Б.С.К., 2000. 316 с.

Фрейд З. Введение в психоанализ. Москва : Наука, 1989. 455 с.

Фромм Э. Душа человека. Москва : Мир, 1992. 429 с.

Хорни К. Память, импринтинг и мозг. Москва : Мир, 1988. 343 с.

Эриксон Э. Идентичность. Москва : Наука, 1996. 344 с.

Blagovechtchenski, E., Gnedykh, D., Kurmakaeva, D., Mkrtychian, N., Kostromina, S., \& Shtyrov, Y. Transcranial direct current stimulation (tDCS) of Wernicke's and Broca's areas in studies of language learning and word acquisition. Journal of Visualized Experiments, 2019, 37-59. URL : https://doi.org/10.3791/59159.

Brédart, S. Word interruption in self-repairing. Journal of Psycholinguistic Research, 1991, 20, 123-137. URL : https://doi.org/10.1007/ bf01067879.

Crookes, G. Planning and interlanguage variation. Studies in Second Language Acquisition, 1989, 11, 367-383. URL : https://doi.org/ $10.1017 / \mathrm{s} 0272263100008391$.

Mykhalchuk, N., \& Ivashkevych, E. Psycholinguistic Characteristics of Secondary Predication in Determining the Construction of a Peculiar Picture of the World of a Reader. Psycholinguistics. Психолінгвістика. Психолингвистика, 2019, 25 (1), 215-231. DOI 10.31470/2309-1797-2019-25-1-215-231.

Mykhalchuk, N., \& Kryshevych, O. The peculiarities of the perception and understanding of Sonnets written by W. Shakespeare by the stu-

(C) Hlavinska Elina

DOI (article): https://doi.org/10.32626/2227-6246.2021-54.09-33 
dents of the Faculty of Foreign Languages. Psycholinguistics. Психолінгвістика. Психолингвистика. Серія: Психологія, 2019, 26 (1), 265-285. DOI 10.31470/2309-1797-2019-26-1-265-285.

Mykhalchuk, N., \& Onufriieva, L. Psycholinguistic features of representation of emotions by the concept of «Fear». Збірник наукових праиь «Проблеми сучасної психологї̈, 2020, 48, 206-227. DOI https:// doi.org/10.32626/2227-6246.2020-48.206-227.

Vovk, M., Emishyants, O., Zelenko, O., Drobot, O., \& Onufriieva, L. Psychological Features of Experiences of Frustration Situations in Youth Age. International Journal of Scientific \& Technology Research, January 2020, 8 (01), 920-924. URL : http://www.ijstr.org/ paper-references.php?ref=IJSTR-0120-28117.

\section{References}

Adler, A. (1998). Vospitaniie detei. Vzaimodeistviie polov [Parenting. Interaction of sexes]. Rostov-na-Donu : Feniks [in Russian].

Ball, H.O. (1996). Pro psykholohichnyi zmist vilnoho rozvytku osobystosti [About the psychological content of free development of the personality]. Psykholohichni aspekty humanizatsii osvity - Psychological aspects of humanization of education, 53-67. Kyiv - Rivne [in Ukrainian].

Bütner, C. (1991). Zhit s agressivnymi detmi [Living with aggressive children]. Moskva : Pedagogika [in Russian].

Winnicott, D.V. (1994). Razgovor s roditeliami [A talk with parents]. Moskva : Klass [ in Russian].

Honcharuk, N., \& Onufriieva, L. (2018). Psykholohichnyi analiz rivniv pobudovy komunikatyvnykh dii [Psychological analysis of the levels of construction of communicative actions]. Psycholinguistics. Psykholinhvistyka. Psikholingvistika - Psycholinguistics. Psycholinguistics. Psycholinguistics, 24 (1), 97-117. Retrieved from https://doi.org/ 10.31470/2309-1797-2018-24-1-97-117 [in Ukrainian].

Dreikurs, R. (1986). Schastie vashego rebenka: kniga dlia roditelei [Your Child's Happiness: A Book for Parents]. Moskva : Progress [in Russian].

Freud, A., \& Freud, Z. (2000). Detskaia seksualnost i psikhoanaliz detskikh psikhonevrozov [Child sexuality and psychoanalysis of child psychoneuroses]. Sankt-Peterburg : B.S.K. [in Russian].

Freud, Z. (1989). Vvedeniie v psikhoanaliz [Introduction to Psychoanalysis ]. Moskva : Nauka [in Russian].

Fromm, E. (1992). Dusha cheloveka [Human soul]. Moskva : Mir [in Russian].

(C) Hlavinska Elina

DOI (article): https://doi.org/10.32626/2227-6246.2021-54.09-33 
DOI: https://doi.org/10.32626/2227-6246.2021-54

2021. випУск 54

Erickson, E. (1996). Identichnost [Identity]. Moskva : Nauka [in Russian]. Kovalev, S.V. (1987). Psikhologiia semeinykh otnoshenii [The Psychology of family relationships]. Moskva : Pedagogika [in Russian].

Kompliienko, I.O. (2020). Teoretychnyi analiz problemy dezadaptyvnykh vzaiemostosunkiv batkiv ta ditei [Theoretical analysis of the problem of maladaptive relationships between parents and children]. Aktualni problemy psykholohii. Metodolohiia i teoriia psykholohii: Zb. nauk. prats Instytutu psykholohii im. H.S. Kostiuka NAPN Ukrainy - Current problems of Psychology. Methodology and Theory of Psychology: Collection of research papers of H.S. Kostiuk Institute of Psychology of NAPS of Ukraine, XIV (3), 99-113. Kyiv - Nizhyn [in Ukrainian].

Maksymenko, S., Tkach, B., Lytvynchuk, L., \& Onufriieva, L. (2019). Neiropsykholinhvistychne doslidzhennia politychnykh hasel iz zovnishnoi reklamy [A neuropsycholinguistic research of political slogans from outdoor advertising]. Psycholinguistics. Psykholinhvistyka. Psikholingvistika - Psycholinguistics. Psycholinguistics. Psycholinguistics, 26 (1), 246-264 [in Ukrainian].

Horney, K. (1988). Pamiat, imprinting $i$ mozg [Memory, imprinting and the brain]. Moskva : Mir [in Russian].

Blagovechtchenski, E., Gnedykh, D., Kurmakaeva, D., Mkrtychian, N., Kostromina, S., \& Shtyrov, Y. (2019). Transcranial direct current stimulation (tDCS) of Wernicke's and Broca's areas in studies of language learning and word acquisition. Journal of Visualized Experiments, 37-59. Retrieved from https://doi.org/10.3791/59159.

Brédart, S. (1991). Word interruption in self-repairing. Journal of Psycholinguistics Research, 20, 123-137. Retrieved from https://doi.org/ $10.1007 / \mathrm{bf} 01067879$.

Crookes, G. (1989). Planning and interlanguage variation. Studies in Second Language Acquisition, 11, 367-383. Retrieved from https://doi.org/ $10.1017 / \mathrm{s} 0272263100008391$.

Mykhalchuk, N., \& Ivashkevych, E. (2019). Psycholinguistic Characteristics of Secondary Predication in Determining the Construction of a Peculiar Picture of the World of a Reader. Psycholinguistics. Psykholinhvistyka. Psikholingvistika - Psycholinguistics. Psycholinguistics. Psycholinguistics, 25 (1), 215-231. Retrieved from https:// doi.org/10.31470/2309-1797-2019-25-1-215-231.

Mykhalchuk, N., \& Kryshevych, O. (2019). The peculiarities of the perception and understanding of Sonnets written by W. Shakespeare by the students of the Faculty of Foreign Languages. Psycholinguistics. Psykholinhvistyka. Psikholingvistika - Psycholinguistics. Psycholinguistics. Psycholinguistics, 26 (1), 265-285. Retrieved from https:// doi.org/10.31470/2309-1797-2019-26-1-265-285.

(C) Hlavinska Elina

DOI (article): https://doi.org/10.32626/2227-6246.2021-54.09-33 
Mykhalchuk, N., \& Onufriieva, L. (2020). Psycholinguistic features of representation of emotions by the concept of «Fear». Zbirnyk naukovykh prats "Problemy suchasnoi psykholohii» - Collection of research papers "Problems of modern psychology», 48, 206-227. Retrieved from https://doi.org/10.32626/2227-6246.2020-48.206-227.

Vovk, M., Emishyants, O., Zelenko, O., Drobot, O., \& Onufriieva, L. (2020). Psychological Features of Experiences of Frustration Situations in Youth Age. International Journal of Scientific \& Technology Research, 8 (01), January, 920-924. Retrieved from http://www. ijstr.org/paper-references.php?ref=IJSTR-0120-28117.

\section{Главінська Еліна. Характеристика феномену адаптації як активного психологічного процесу}

\section{АНОТАЦІЯ}

Мета статmі - показати процес адаптації як активний психологічний процес, на який впливають як зовнішні (об'єктивні), так і внутрішні (суб'єктивні) чинники; обгрунтувати основні ідеї раціогуманістичного підходу, психоаналітичного напряму, конативної та когнітивної моделей адаптивної поведінки, соціально-психологічного напряму психологічної адаптації.

Для розв'язання поставлених у роботі завдань використано такі теоретичні методи дослідження: категоріальний, структурно-фрункціональний, аналіз, систематизація, моделювання, узагальнення.

Результати дослідження. Дезадаптивна поведінка здійснювалася з урахуванням певної конкретної мети. Особистість із такою поведінкою, як правило, вимагала пильної уваги до здійснення нею певних дій. Така людина могла завдати неабиякого занепокоєння, демонструвати роздратування, особливо якщо діти хотіли, щоб батьки за будь-яких умов їх помічали, приділяли їм більше часу, уваги тощо. Демонстративна деструкція дітей у більшості випадків є наслідком певної досить-таки помилкової думки дітей щодо того, що вони могли в будь-якому разі самоствердитися, наполягти на миттєвому виконанні батьками своїх мрій і бажань. Отже, діти хотіли довести, що завдяки деструкціям вони продемонструють свою силу в протистоянні з дорослими. При цьому помста, відплата, бажання спричинити біль іншим нерідко здавалися дітям лише єдиним можливим способом відчути себе особистісно значущими та неповторними.

(c) Hlavinska Elina

DOI (article): https://doi.org/10.32626/2227-6246.2021-54.09-33 
DOI: https://doi.org/10.32626/2227-6246.2021-54

2021. випуск 54

Дитина, наголошуючи на своїй недосконалості або неповноцінності, як правило, експлікувала власну неспроможність до виконання певної діяльності. У таких ситуаціях дитина не хотіла комунікувати з дорослими, зокрема з батьками, не виявляла бажання виконувати їх доручення, ставилася досить безвідповідально до життєвих сценаріїв і планів.

Висновки. Вважаємо, що у разі виявлення дезадаптованих взаємостосунків батьків і дітей психолог повинен допомогти як дітям, так і дорослим. Усі вони в кінцевому підсумку повинні опанувати велику кількість різних типів соціальної взаємодії. Остання має вибудовуватися на основі таких, що не повною мірою співпадають, але досить-таки близьких за смислом уявлень щодо цінностей, взаємного прийняття батьками й дітьми один одного. Отже, одне з основних завдань сімейного виховання-допомогти дитині досягти компетентності у здійсненні життєвих сценаріїв, що свідчитиме про те, що ця дитина буде здатна самостійно, без допомоги з боку інших осіб використовувати конструктивні психологічні механізми, фрейми, скрипти і засоби для становлення відчуття власної гідності й опанування певним, найбільшою мірою значущим для дитини суспільним становищем.

Показано, що ідеї А. Адлера (1998) і Р. Дрейкурса (1986) є, поза будьяким сумнівом, вельми актуальними. Ці ідеї пов'язані з тією кризою, уякій опинилася звичайна сім'я в першій половині минулого століття. Традиційні взаємостосунки між батьками й дітьми, які вибудовувалися з урахуванням механізмів домінування і підпорядкування, виявилися досить-таки неефективними. На думку багатьох учених, батьки, які спілкувалися зі своїми дітьми з позицій влади, домінування, першовартості, взагалі, як правило, не усвідомлювали того, що їхні діти могли сприймати їх як рівних партнерів по спілкуванню. Розмова батьків із дітьми за вертикаллю «зверху вниз» призвела до того, що діти так само спілкувалися зі своїми однолітками, вчителями, іншими дорослими, сторонніми людьми, або взагалі «йшли» в себе, намагаючись не реагувати на батьків, дорослих і, врешті-решт, починали зневажати ї.

Обгрунтовано, що Р. Дрейкурс був одним із перших учених-практиків, хто організував групову тренінгову роботу батьків із метою адаптації дітей до життєдіяльності. Учений виходив із того, що батьки у процесі групових зустрічей мають намір обмінюватися між собою набутим особистісно значущим досвідом, будуть намагатися ставити запитання, прагнути отримати певну підтримку й схвалення тренінгової групи. (C) Hlavinska Elina

DOI (article): https://doi.org/10.32626/2227-6246.2021-54.09-33 
При цьому основним завданням тренера було створення позитивних передумов із метою продуктивної організації роботи у групі. Завдяки цьому тренер мав можливість сформулювати запитання так, щоб кожен член тренінгової групи виконував роль лідера, який не лише обмінювався певною інформацією, а й формулював спечіальні завдання, задачі та проблемні ситуації, які інші члени групи мали розв'язати.

Ключові слова: адаптація, деструктивна поведінка, демонстративна непокора, демонстрація реального чи уявного безсилля, випадок конфронтації з дорослими.

Главинская Элина. Характеристика феномена адаптации как активного психологического прочесса

\section{АННОТАЦИЯ}

Цель статьи - описать процесс адаптации как активный психологический процесс, на который влияют как внешние (объективные), так и внутренние (субъективные) факторы; обосновать основные идеи рациогуманистического подхода, психоаналитического направления, конативной и когнитивной моделей адаптивного поведения, социально-психологического направления психологической адаптации.

Для решения поставленных в работе задач использованы следующие теоретические методы исследования: категориальный, структурно-функциональный, анализ, систематизация, моделирование, обобщеHUе.

Результаты исследования. Доказано, что дезадаптивное поведение осуществлялось с учетом определенной конкретной цели. Личность с таким поведением, как правило, требовала пристального внимания к совершению ею определенных действий. Такой человек может создавать большое беспокойство, демонстрировать раздражение, особенно если дети хотели, чтобы родители при любых условиях их замечали, уделяли им больше времени, внимания. Демонстративная деструкция детей в большинстве случаев являлась следствием определенного довольно-таки ошибочного мнения детей о том, что они могли в любом случае самоутвердиться, настоять на мгновенном исполнении родителями своих мечт и желаний. В таком случае дети хотели доказать, что благодаря именно деструкции они продемонстрируют свою силу в противостоянии со взрослыми. При этом месть, возмездие, желание причинить

(C) Hlavinska Elina

DOI (article): https://doi.org/10.32626/2227-6246.2021-54.09-33 
боль другим нередко казались детям только единственно возможным способом почувствовать себя личностно значимыми и неповторимыми.

Ребенок, подчеркивая свое несовершенство или неполноценность, как правило, эксплицировал собственную неспособность к выполнению определенной деятельности. В таких ситуациях ребенок не хотел коммуницировать со взрослыми, в частности с родителями, не проявлял желания выполнять их поручения, относился достаточно безответственно к жизненным сценариям и планам.

Выводы. Мы считаем, что в случае выявления дезадаптированных взаимоотношений родителей и детей психолог должен помогать как детям, так и взрослым. Все они в конечном счете должны овладеть большим количеством различных типов сочиального взаимодействия. Последнее выстраивалось на основе таких взаимодействий, которые не в полной мере совпадают, но довольно-таки близки по смыслу представлений о ценностях, на взаимном принятии родителями и детьми друг друга. Таким образом, одной из основных задач семейного воспитания являлась помощь ребенку достичь компетентности в осуществлении жизненных сценариев, что будет свидетельствовать о том, что этот ребенок будет способен самостоятельно, без помощи со стороны других лич использовать конструктивные психологические механизмы, фреймы, скрипты и средства для становления чувства собственного достоинства и освоения определенным, в наибольшей степени значимым для ребенка общественным положением.

Показано, что идеи А. Адлера (1998) и Р. Дрейкурса (1986) являлись, вне всякого сомнения, весьма актуальными. Эти идеи связаны с тем кризисом, в котором оказалась обычная семья в первой половине прошлого века. Традиционные взаимоотношения между родителями и детьми, которые выстраивались с учетом механизмов доминирования и подчинения, оказались довольно-таки неэффрективными. Показано, что, по мнению многих ученых, родители, которые общались со своими детьми с позиций власти, доминирования, совершенства, вообще, как правило, не осознавали того, что дети могли воспринимать их как равных партнеров по общению. Разговор родителей с детьми по вертикали «сверху вниз» привел к тому, что дети таким же образом общались со своими сверстниками, учителями, другими взрослыми, посторонними людьми, или вообще "уходили» в себя, стараясь не реагировать на родителей, взрослых, и, в конце концов, начинали презирать их.

(C) Hlavinska Elina

DOI (article): https://doi.org/10.32626/2227-6246.2021-54.09-33 
DOI: https://doi.org/10.32626/2227-6246.2021-54

2021. ВИПУСК 54

Обосновано, что Р. Дрейкурс был одним из первых ученых-практиков, кто организовал групповую тренинговую работу родителей с целью адаптации детей к процессу жизнедеятельности. Ученый исходил из того, что родители в процессе групповых встреч имеют намерение обмениваться между собой приобретенным личностно значимым опытом, будут пытаться задавать вопросы, стремиться получить определенную поддержку и одобрение всей тренинговой группы. При этом основной задачей тренера было создание положительных предпосылок с целью продуктивной организации работы в группе. Тренер должен срормулировать вопросы таким образом, чтобы каждый член тренинговой группы имел возможность выполнять роль лидера, а также не только обмениваться определенной информацией, но и формулировать специальные задания, задачи, проблемные ситуации, которые другие члены группы должны решить.

Ключевые слова: адаптация, деструктивное поведение, демонстративное неповиновение, демонстрация реального или воображаемого бессилия, случай конфронтации со взрослыми.

Original manuscript received July 19, 2021

Revised manuscript accepted September 01, 2021 